\title{
Smart Tourism as a Pillar for Sustainable Urban Development: An Alternate Smart City Strategy from Mauritius
}

\author{
Yeshna Jessie Dabeedooal ${ }^{1}$, Vickramsingh Dindoyal ${ }^{1}$, Zaheer Allam ${ }^{2, *(D)}$ and David S. Jones ${ }^{3}$ (D) \\ 1 Elite Business School, Ebène, Plaines Wilhems 72201, Mauritius; jessiedabee@gmail.com (Y.J.D.); \\ vickdindoyal@gmail.com (V.D.) \\ 2 Curtin University Sustainability Policy Institute, Curtin University, Perth 6845, Australia \\ 3 School of Architecture \& Built Environment, Deakin University, Geelong 3220, Australia; \\ david.jones@deakin.edu.au \\ * Correspondence: zaheerallam@gmail.com
}

Received: 27 March 2019; Accepted: 26 April 2019; Published: 5 May 2019

\begin{abstract}
Mauritius, a small island developing state (SIDS), has an approved government-issued smart city framework geared at facilitating the development of smart cities through an application of Internet of things. In an attempt to move away from privately-operated urban developments in the form of newly built smart cities, an alternate framework has been proposed by Allam and Newman to redefine this timely concept for existing cities with the main dimensions being metabolism, culture, and governance. This new framework focuses on liveability and sustainability that builds on the cultural and historical dimensions of existing cities. This study adds to the redefined smart city paradigm by proposing a new pillar in the form of smart tourism for the city of Port Louis, Mauritius. This paper reviews models of smart tourism and explores how this can be grafted to the Allam and Newman's smart city model. The findings of this study seek to inform policy makers on alternate and the more relevant economic potential of smart tourism for the city of Port Louis.
\end{abstract}

Keywords: smart tourism; smart cities; mauritius; sustainability; economy

\section{Introduction}

As the concept of a smart city gains traction globally, it has been observed that this concept has predominantly been driven by the private sector, and hence is concentrated in the real estate arena [1-5]. In particular, as Barkham, Bokhari, and Saiz [2] explain, this concept has increased the potential for city managers to counter challenges, such as housing affordability, increased traffic, biodiversity loss, and security issues, amongst others, that are prompted by the increasing urban population, and parallel rapid urbanisation. Interestingly, the attractiveness of cities is often increased through effective branding and characterization identity-making strategies because the concept attracts improved real estate profitability [6].

However, beyond the real estate dimension, technology inherent to the smart city concept has been proven to have the potential in boosting other dimensions of the city $[7,8]$. For example, sectors, like culture and tourism, can be oriented to foster increased liveability and to strengthen the resilience of urban fabric especially in regards to job creation, employment, increased revenues, and in promoting other associated sectors [9]. Cities like Singapore and Kuala Lumpur have capitalized on their 'smart' brand to position themselves as international tourist attractions, a strategy that has helped them grow their economies exponentially [10,11]. 'Touristification' has thereupon been re-cast to benefit these two nations through enhanced technological throughputs and synergies. For instance, the availability of numerous smart devices, sensors, systems, and advanced technologies, such as the Internet of Things 
(IoT), big data, and artificial intelligence, allows for real-time solutions and actions to different issues in the city [12-14].

These technologies are vital in improving transport and communication infrastructures, improving human security and safety, allowing for interlinkages of different services, and in improving the 'sustainability' or 'liveability' status of the city [15]. All of these initiatives help in building both a brand and a lifestyle that many tourists and residents alike seek out. Liberato et al. [16] argue that with such improvements, the 'customer experience' is improved, and the attraction and retention of people becomes easier. All of which helped in moulding a conducive environment for foreign direct investments (FDIs), which includes investment in the hospitality industry that is the cornerstone of the tourism sector.

One specific area that has the potential to benefit from smart technologies is the cultural and creative industries [17-19]. This sector plays a critical role in job creation, employment, and in the economic growth of cities. However, technologies associated to smart cities need to be re-calibrated to benefit the urban fabric while promoting its cultural attributes [20]. This is especially so when it is aligned with technologies that support the interlinkage of different components and availability of massive data that is generated from different smart components once installed [21]. With data and information, industry benefits by increasing productivity brought about by having access to specialists and a skilled labour force derived from innovations enabled by technology, including, above all, from the availability and access to information and resources that would not normally be enabled otherwise.

This paper offers a review of the literature and proposes smart tourism as a new pillar for Allam and Newman's [17] redefined smart city paradigm. The findings of this study seek to inform policy makers on the economic and social developmental potential of smart tourism for the city of Port Louis in Mauritius.

\section{Smart Cities, Culture, and Tourism in Mauritius}

Mauritius, a small island developing state (SIDS), with a land area of $2040 \mathrm{~km}^{2}$, is located in the middle of the Indian Ocean. This SIDS boasts a highly diverse ethnicity owing to its colonial past. Evolving from a monocrop economy in the early 1960s to a diverse economy, Mauritius has seen a boost in its GDP from US $\$ 4.869$ billion in the year 2000 to US $\$ 13.34$ billion in 2017 with the tourism industry contributing $23.8 \%$ to Mauritius' total GDP for 2017. This contribution is expected to reach $26.1 \%$ by 2028 [22]. This growth in tourism has also been accompanied with a prominent development and visual transformation of the landscape and architecture disciplines and policies within the government of Mauritius. One key precedent has been the introduction of a smart city framework that offers fiscal and non-fiscal incentives for promoters that seek to convert green-fields into smart cities under the banner of work, live, and play [4,23]. However, Allam and Newman [17] have gone beyond the mainstream market-centred smart city paradigm applied by Mauritius and proposed a redefined smart city model based upon the pillars of culture, metabolism, and governance. This latter model is geared essentially towards sustainably boosting liveability in existing cities.

One key dimension missing in the Allam and Newman model, but which is a hallmark feature of most SIDS economies, is tourism. The tourism industry pervades into all aspects of a SIDS society more than any other industry [24], and improper tourism development can disrupt the main economic, social, and environmental fabric of a SIDS society [25]. Gunn [24] has observed that the need for a shared vision and action plan of all stakeholders is required to ensure the successful implementation of sustainable tourism development. Sustainable development is essentially linked to development that caters for the present needs without jeopardising the ability of future generations to do the same [26]. Literature links sustainable development to social, economic, and environmental dimensions of development [27], and circular economies [26,28]. However, in the case of tourism, there are calls for involving residents at all stages of development for community based tourism [29].

As pointed out by Scheyvens and Momsen [30], SIDS are amongst the most dependent nations upon tourism for their economies, and it is the only industry which has shown continuous growth 
historically in many SIDS. However, there is a relative gap in policies in SIDS in providing for better development through tourism [30,31].

There have been calls for promoting domestic tourism in SIDS to ensure sustainability in the sector [32], while other studies have commended the need for considering market needs to ensure economic viability and environmental sustainability of the tourism industry [33]. Nonetheless, these authors recognise the "very limited" evidence of the robustness of actual adaptations measures. There have been monitoring studies for sustainable tourism development in a specific island [34], and there has been one instance in which the tourism industry, comprising a sustainable development industry exemplar for all SIDS, has been completely dispelled [35]. There is thus a need to seek novel approaches to create novel pillars of sustainable tourism or capitalise on less popular market niches. Exploring this line of thought, Korez-Vide [36] extols the importance of culture-based creativity as a driver for sustainable tourism development. Through a model of sustainable creative tourism, Korez-Vide [36] sought to achieve proper socio-economic and environmental balance, a hallmark feature of sustainability.

However, it is to be noted that there has been a relentless rise in urbanisation ever since the industrial revolution. Already, more than half of the world's population is a city-dweller despite the fact that cities are major polluters and contribute very little to the creation of resources [37]. With the parallel rise in urban tourism, there can be a very unsustainable outcome that can fracture the social integrity of cities [38]. Nonetheless, urban tourism has also been perceived as a major driver for economic growth [39], and there are studies that recommend further research into the dynamics of urban tourism owing to its huge impact upon city dwellers and infrastructure [40-42]. Della Lucia et al. [43] highlight the relative lack of analysis about how cities can capitalise on their cultural heritage to promote sustainable tourism development. This begs the question of how cities in SIDSs cope with the need for better management whilst seeking novel pillars of economic development in this digital era. To this end, this study seeks to bridge this gap in knowledge by proposing smart tourism as a new pillar for Allam and Newman's redefined smart city paradigm [17].

\section{Theoretical Background}

\subsection{Smart Cities}

Joss et al. [44] highlight the ubiquitous presence of the smart city in literature, but acknowledge a lack of consensual definition of the same. The smart city paradigm is being hailed in the literature as the application of the IoT coupled with big data capture and analyses leading to data-backed governance [45-47]. The smart city paradigm is also being hailed as being most relevant to best practice in urban management [44]. Digitally-enhanced cities are being put forward and are being hailed as exemplar solutions to the contemporary ailments of urban areas, enticing urban citizens to aspire to 'construct' more sustainable and liveable cities [48-52]. However, the development of smart cities from the ground up, as is the ongoing practice in Mauritius, may lead to a business drain and cultural erosion from existing cities in the immediate vicinity of mushrooming smart cities $[17,53]$. To break away from these corporate-led smart city development in green fields, Allam and Newman [17] proposed a novel smart city framework (Figure 1) for existing cities, which aims at capitalising on the human dimension while reducing urban metabolism and enhancing liveability.

Such a model lays emphasis on urban sustainability in triggering investment in cultural heritage [54], and the development of creative industries [55]. Allam [4] applied this model together with findings of a focused group study to propose a smart urban regeneration for the city of Port Louis. This city, the capital of Mauritius, hosts major governing and judicial bodies together with business activities of the island nation through the only trade port of the island. The proposed smart urban regeneration scheme (Figure 2) relies on pillars of smart infrastructure, culture, metabolism, and governance. 


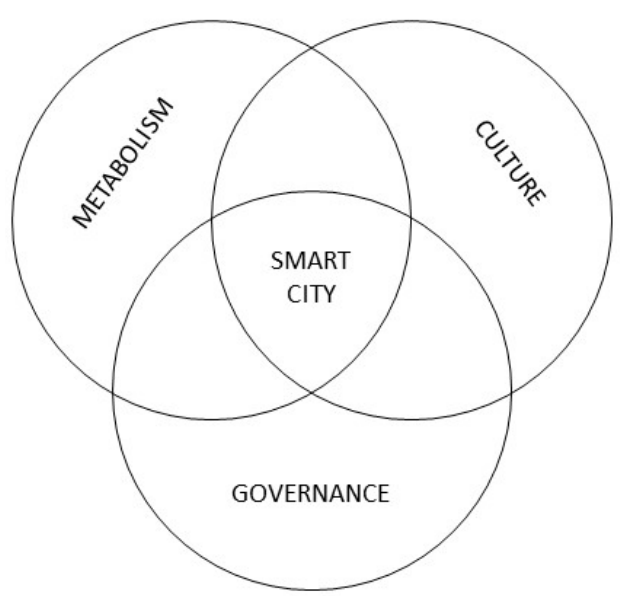

Figure 1. Smart city framework (Source: Allam and Newman [17]).

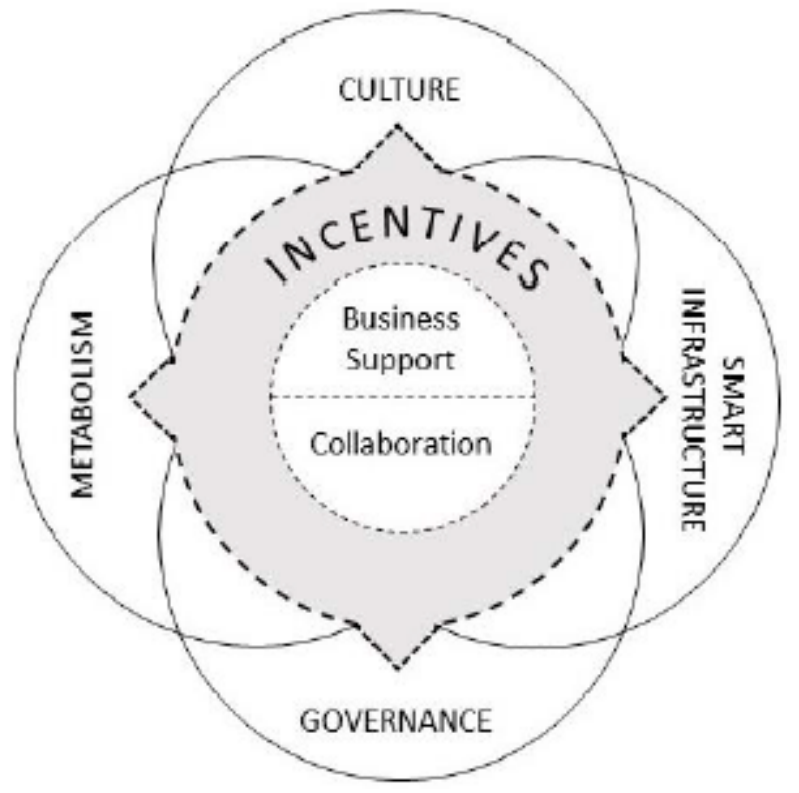

Figure 2. The smart urban regeneration framework (Source: Allam [4]).

This framework also aims at curbing the effects of urban decay that might occur to existing cities facing uneven competition from highly incentivised new-corporate led smart cities. To increase their competitiveness, economic resilience, and liveability within a sustainable base, existing cities need to adapt and find new pillars of economy or explore existing pillars under a new light. In the case of Port Louis, it is already a major tourist attraction in Mauritius and previous studies already evidence that through the right governance, the city could actually be revamped through adoption of a smart city framework as defined by [4]. So, why not through smart tourism?

\subsection{Smart Tourism}

Smart tourism relates to the use of large data inputs coupled with technological outputs used by people for responding to changing environments or situations [56]. Although the concept of being 'smart' has been essentially associated with cities towards optimising the use of technology for achieving effective resource management, liveability, sustainability, and enhanced governance [8,57], its association with tourism relates to all these dimensions in an intricate manner [57]. Despite most research relating smart tourism to the use of Information and Communications Technology (ICT) [58-60] and Internet of things [61,62], there is need to distinguish between the conceptual ideology 
of smart tourism and the actual framework for smart tourism destination(s). The latter being actual cities which have invested in infrastructural upgrades to cater for the tech-savvy tourist.

Gretzel, Sigala, Xiang, and Koo [57] explain smart tourism as being multi-layered in dimension with the connecting thread being the ICT core (Figure 3). The three main pillars of their model are the smart experience, the smart business ecosystem, and the smart destination linked to data analysis through collection, exchange, and processing.

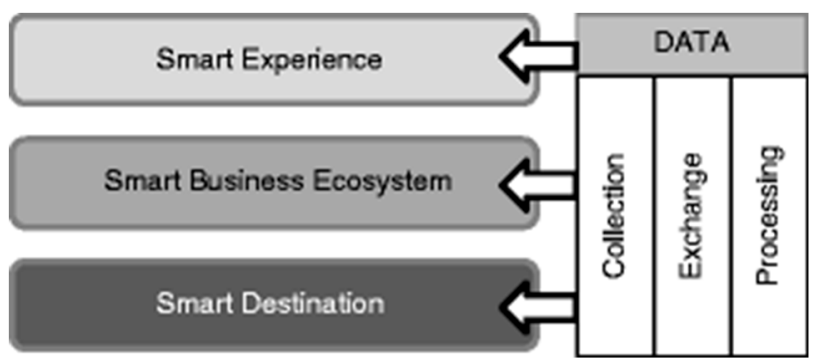

Figure 3. Key components and layers of smart tourism (Source: Gretzel, Sigala, Xiang, and Koo [57]).

The focus of the smart dimension in their model is the ubiquitous application of ICT and IoT to urban infrastructure to facilitate the tourist's experience through a digital platform. For instance, Barcelona, in Spain, offers interactive bus shelters that not only provide easy access to information to tourists, but also allow them the ability to recharge their mobile devices. Another example includes Brisbane, in Australia, which hosts hotspots that relays information to tourists [57], or Geelong, in Australia, that offers free Wi-Fi service with add on tourism apps to all visitors and city users. The smart experience highlights the essential role of the tourist from a social point of view. Here, the onus lies on both usage and contribution to data-backed services. The urban ICT-backed infrastructure and the tourist's smart experience contribute to the smart business ecosystem, which Gretzel, Sigala, Xiang, and Koo [57] describe as public-private collaboration leading to the setting-up and maintenance of resources that ensures a smart experience within a smart destination.

Lamsfus, Martín, Alzua-Sorzabal, and Torres-Manzanera [60] explored the smart destination ICT infrastructure and designed an architectural framework for the latter (Figure 4). This model consists of three core modules of a mobile web content editor, context-aware, and mobile analytics platform, which together links tourism service providers/ICT companies and visitors. The key focus is to design and provide tailor-made web-based services for the tourist and gather their responses to continue to upgrade on the service.

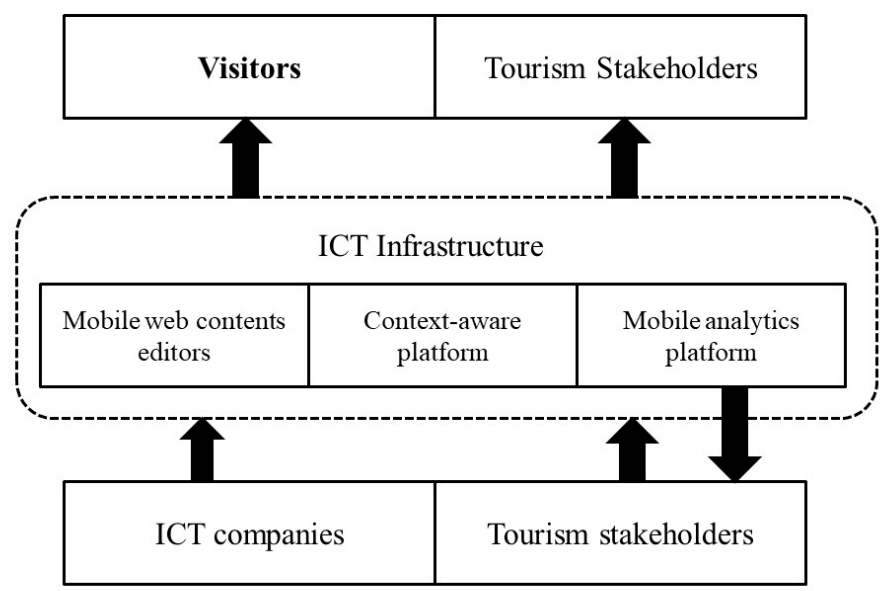

Figure 4. Architecture for smart destination Information and Communications Technology (ICT) infrastructure (Source: Lamsfus, Martín, Alzua-Sorzabal, and Torres-Manzanera [60]). 
From a conceptual point of view, Boes, Buhalis, and Inversini [59] provide a framework for a smart tourism destination (Figure 5). This model draws from case studies of Barcelona, Amsterdam, and Helsinki as smart destinations. These authors extol the need for strong and committed leadership within the hallmark dimensions of entrepreneurship and innovation to bring forth enhanced social capital that will cater for optimised liveability.

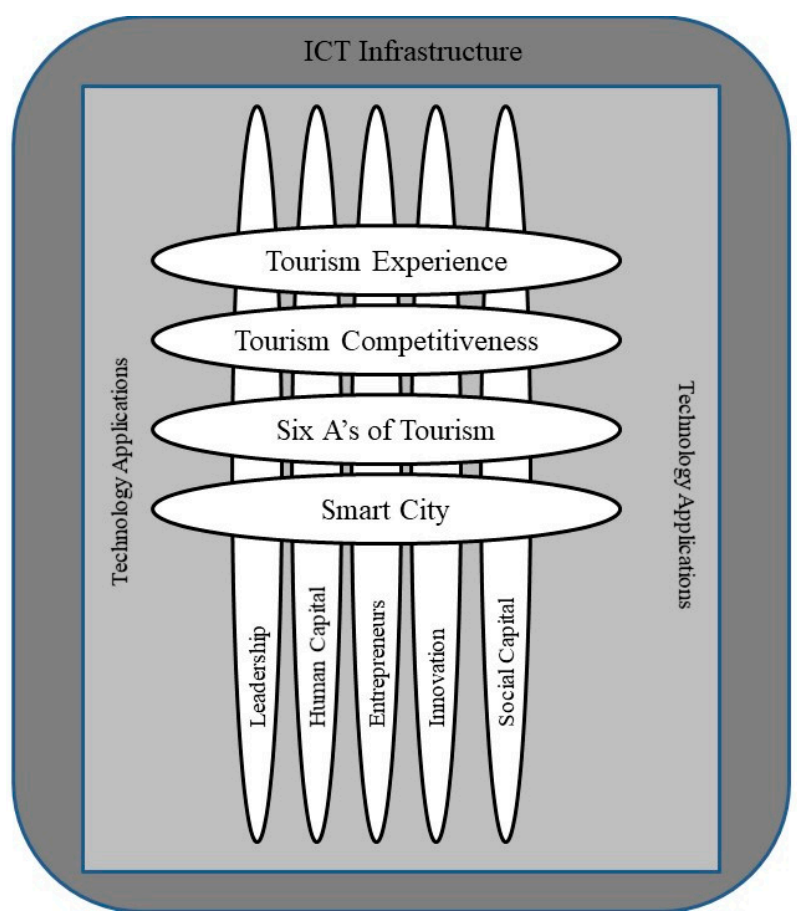

Figure 5. Framework for smart tourism destination (Source: Boes, Buhalis, and Inversini [59]).

\section{Discussion}

Port Louis can 'leap frog' into the 21st century through the novel concept of smart tourism. As Ramkissoon and Nunkoo [63] pointed out, the right governance drive together with an inclusive approach with the city residents will provide a conducive environment for tourism development. Building from the findings of Boes, Buhalis, and Inversini [59]; Gretzel, Sigala, Xiang, and Koo [57]; Lamsfus, Martín, Alzua-Sorzabal, and Torres-Manzanera [60]; and Allam and Newman [18], the proposed smart tourism pillar rests on key indicators of (i) smart infrastructure, (ii) smart business, (iii) governance, and (iv) urban metabolism, as depicted in Figure 6.

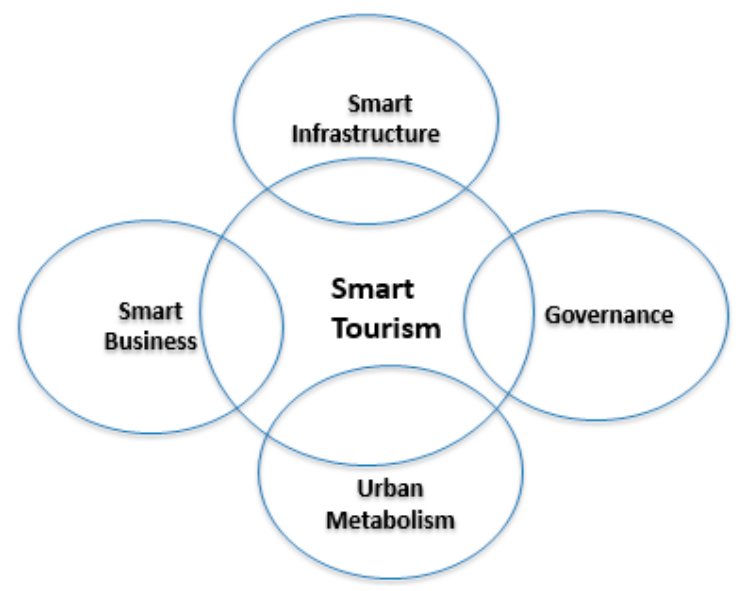

Figure 6. Proposed dimensions for smart tourism for Port Louis (Illustration sourced by authors). 
Smart infrastructure forms the core of smart tourism whereby Internet of things coupled with smart devices can enhance the overall experience of the visitor. However, 'smartness' is all about the interlinking of smart devices with the right service provider at the right time for the correct purpose [64]. This experience needs to be as close as possible to real time data analyses and sharing through appropriate algorithms in a bid to ensure better outcomes [65]. To this end, there is need to establish a tailor-made ICT infrastructure whereby mobile contents are contextualised together with a clearly defined mobile analytics platform [60]. Nonetheless, before inherent development of the ICT infrastructure, there is need to shortlist businesses that will be needed to make Port Louis a smart tourist destination. Buhalis and Amaranggana [58] hail the ' $6 \mathrm{~A}$ 's of tourism destinations that contribute to success as being:

(1) Attractions (e.g., physical landmarks, culture, parks);

(2) Accessibility (e.g., transportation services);

(3) Amenities (e.g., leisure, accommodation, food);

(4) Available packages (e.g., service bundles);

(5) Activities;

(6) Ancillary services (eg. postal services, banks, hospitals).

All businesses linked to the 6As should be linked to ICT infrastructure. Such ubiquitous use of IoT and smart devices calls for better cyber security [66], hence the need for appropriate governance. The genesis of a new smart destination needs to have a leader to actively engage with local inhabitants and to ensure the monitoring of plans in a bid to ensure smooth implementation and appropriate flow of data with an emphasis on accountability and transparency [58]. To ensure that Port Louis caters for the liveability of all inhabitants and visitors while maintaining high standards for sustainability, the urban metabolism of the city should be closely monitored. This will provide feedback for corrective mechanisms to gear up in an event of unsustainability.

\section{Conclusions}

This paper builds on the redefined smart city framework advocated by Allam and Newman [17], and explores the possibility of adding smart tourism as a novel pillar to it. Tourism is being considered because it directly contributes greatly to both the economic and societal dimensions of a city. As such, the proposed model also dwells on Allam's urban regeneration scheme for the city of Port Louis and proposes smart tourism as a key pillar for the city. The smart tourism pillar being proposed is supported by key drivers of smart infrastructure, smart business, metabolism, and governance while integrating the role of ICT and technologies inherent to the smart city concepts. The city of Port Louis has been considered as in links to the previous works of Allam and Newman [17], where the core purpose of a redefined smart city paradigm is the need to promote liveability and to capitalise on cultural and historical dimensions of the city. Port Louis is the capital city of Mauritius with a rich cultural and historical background together with the fact that it is one of the most visited tourist cities of the island.

Author Contributions: Conceptualisation, methodology, formal analysis, and writing-original draft preparation, Y.J.D., V.D., Z.A.; writing-review and editing, D.S.J.

Funding: This research received no external funding.

Conflicts of Interest: The authors declare no conflict of interest.

\section{References}

1. Lafortezza, R.; Chen, J.; Van den Bosch, C.K.; Randrup, T.B. Nature-based solutions for resilient landscapes and cities. Environ. Res. 2018, 165, 431-441. [CrossRef]

2. Barkham, R.; Bokhari, S.; Saiz, A. Urban Big Data: City Management and Real Estate Markets; MIT Center for Real Estate and DUSP: Cambridge, MA, USA, 2018. 
3. Eremia, M.; Toma, L.; Sanduleac, M. The Smart City Concept in the 21st Century. Procedia Eng. 2017, 181, 12-19. [CrossRef]

4. Allam, M.Z. Redefining the Smart City: Culture, Metabolism and Governance. Case Study of Port Louis, Mauritius. Ph.D. Thesis, Curtin University, Perth, Australia, 2018. Unpublished.

5. Allam, Z. Building a conceptual framework for Smarting an existing city in Mauritius: The case of Port Louis. J. Biourban. 2017, 4, 103-121.

6. Joss, S.; Cook, M.; Dayot, Y. Smart Cities: Towards a New Citizenship Regime? A Discourse Analysis of the British Smart City Standard. J. Urban Technol. 2017, 24, 29-49. [CrossRef]

7. Woherem, E.E.; Odedra-Straub, M. The Potentials and Challanges of Developing Smart Cities in Africa. Circ. Comput. Sci. 2017, 2, 27-39. [CrossRef]

8. Allam, Z.; Dhunny, Z.A. On big data, artificial intelligence and smart cities. Cities 2019, 89, 80-91. [CrossRef]

9. Iyer, J. The Heart of Smart Cities: A Case for the Relevance of Art in Data Driven Cities; Arts Management \& Technology Laboratory, Carnegie Mellon University: Pittsburgh, PA, USA, 2017; pp. 1-11.

10. Ministry of Foreign Affairs Singapore. Towards a Sustainable and Resilient Singapore; Government of Singapore: Singapore, 2018; pp. 1-84.

11. Tan, K.G.; Chuah, H.Y.; Luu, N.T.D. A case study on Malaysia and Singapore. Compet. Rev. 2018, 28, $172-193$. [CrossRef]

12. Yigitcanlar, T.; Kamruzzaman, M.; Buys, L.; Ioppolo, G.; Sabatini-Marques, J.; da Costa, E.M.; Yun, J.J. Understanding "smart cities": Intertwining development drivers with desired outcomes in a multidimensional framework. Cities 2018, 81, 145-160. [CrossRef]

13. Rathore, M.M.; Paul, A.; Hong, W.; Seo, H.; Awan, I.; Saeed, S. Exploiting IoT and big data analytics: Defining Smart Digital City using real-time urban data. Sustain. Cities Soc. 2018, 40, 600-610. [CrossRef]

14. Bibri, S.E. The IoT for smart sustainable cities of the future: An analytical framework for sensor-based big data applicaitons for environmental sustainability. Sustain. Cities Soc. 2018, 38, 230-253. [CrossRef]

15. Priscila, E.; Hinning, M.P.F.; Costa, E.M.d.; Marques, J.S.; Bastos, R.C.; Yigatcanlar, T. Sustainable development of smart cities: A systematic review of the literature. J. Open Innov. Technol. Mark. Complex. 2017, 3, 11.

16. Liberato, P.; Alen, E.; Liberato, D. Smart tourism destination triggers consumer experience: The case of Porto. Eur. J. Manag. Bus. Econ. 2018, 27, 6-25. [CrossRef]

17. Allam, Z.; Newman, P. Redefining the Smart City: Culture, Metabolism \& Governance. Smart Cities 2018, 1, $4-25$.

18. Allam, Z.; Newman, P. Economically Incentivising Smart Urban Regeneration. Case Study of Port Louis, Mauritius. Smart Cities 2018, 1, 4. [CrossRef]

19. Siew, G.; Allam, Z. Culture as a driver for sustainable urban development. In Proceedings of the UIA 2017 Seoul World Architects Congress, Seoul, Korea, 3-7 September 2017.

20. Angelidou, M.; Karachaliou, E.; Angelidou, T.; Stylianidis, E. Cultural Heritage in Smart City Environments. In Proceedings of the International Archives of the Photogrammetry, Remote Sensing and Spatial Information Sciences, Ottawa, ON Canada, 28 August-1 September 2017.

21. Yang, J.; Černevičiūtè, J. Cultural and Creative Industries (CCI) and sustainable development: China's cultural industries clusters. Enterp. Sustain. Issues 2017, 5, 231-242. [CrossRef]

22. WTTC. Travel and Tourism Economic Impact 2018 Mauritius; World Travel and Tourism Council: London, UK, 2018.

23. EDB. Smart City Scheme Guidelines; Economic Development Board: Port Louis, Mauritius, 2018.

24. Gunn, C. Tourism Planning: Basic Concepts Cases, 3rd ed.; Taylor and Francis: Washington, DC, USA, 1994.

25. Byrd, E.T. Stakeholders in sustainable tourism development and their roles: Applying stakeholder theory to sustainable tourism development. Tour. Rev. 2007, 62, 6-13. [CrossRef]

26. Suárez-Eiroa, B.; Fernández, E.; Méndez-Martínez, G.; Soto-Oñate, D. Operational principles of circular economy for sustainable development: Linking theory and practice. J. Clean. Prod. 2019, 214, 952-961. [CrossRef]

27. Epstein, M.J. Making Sustainability Work: Best Practices in Managing and Measuring Corporate Social, Environmental and Economic Impacts; Routledge: London, UK, 2018.

28. Ivanovic, O.M. Ecological Responsibility and Sustainable Development as Preconditions for Development of the Concept of Circular Economy. In Green Business: Concepts, Methodologies, Tools, and Applications; IGI Global: Hershey, PA, USA, 2019; pp. 1-16. 
29. Lee, T.H.; Jan, F.-H. Can community-based tourism contribute to sustainable development? Evidence from residents' perceptions of the sustainability. Tour. Manag. 2019, 70, 368-380. [CrossRef]

30. Scheyvens, R.; Momsen, J.H. Tourism and poverty reduction: Issues for small island states. Tour. Geogr. 2008, 10, 22-41. [CrossRef]

31. Sharpley, R.; Ussi, M. Tourism and governance in small island developing states (SIDS): The case of Zanzibar. Int. J. Tour. Res. 2014, 16, 87-96. [CrossRef]

32. Place, S.; Hall, C.M.; Lew, A. Sustainable Tourism: A Geographical Perspective; Longman: Harlow, UK, 1998.

33. Hassan, S.S. Determinants of market competitiveness in an environmentally sustainable tourism industry. J. Travel Res. 2000, 38, 239-245. [CrossRef]

34. Twining-Ward, L.; Butler, R. Implementing STD on a small island: Development and use of sustainable tourism development indicators in Samoa. J. Sustain. Tour. 2002, 10, 363-387. [CrossRef]

35. Fagence, M. Tourism as a feasible option for sustainable development in small island developing states (SIDS): Nauru as a case study. Pac. Tour. Rev. 1999, 3, 133-142.

36. Korez-Vide, R. Promoting sustainability of tourism by creative tourism development: How far is Slovenia. Innov. Issues Approach. Soc. Sci. 2013, 6, 77-102. [CrossRef]

37. UN. World Urbanization Prospects - The 2018 Revision; United Nations: Rome, Italy, 2018.

38. Page, S.J. Urban Tourism; Routledge: London, UK, 1995.

39. Law, C.M. Urban Tourism: Attracting Visitors to Large Cities; Mansell Publishing Limited: London, UK, 1993.

40. Ashworth, G.; Page, S.J. Urban tourism research: Recent progress and current paradoxes. Tour. Manag. 2011, 32, 1-15. [CrossRef]

41. Pearce, D.G. An integrative framework for urban tourism research. Ann. Tour. Res. 2001, 28, 926-946. [CrossRef]

42. Selby, M. Understanding Urban Tourism: Image, Culture and Experience; IB Tauris: London, UK, 2004.

43. Della Lucia, M.; Trunfio, M.; Go, F.M. Heritage and Urban Regeneration: Towards Creative Tourism. In Tourism in the City; Springer: Cham, Switzerland, 2017; pp. 179-191.

44. Joss, S.; Sengers, F.; Schraven, D.; Caprotti, F.; Dayot, Y. The smart city as global discourse: Storylines and critical junctures across 27 cities. J. Urban Technol. 2019, 26, 3-34. [CrossRef]

45. Chourabi, H.; Nam, T.; Walker, S.; Gil-Garcia, J.R.; Mellouli, S.; Nahon, K.; Pardo, T.A.; Scholl, H.J. Understanding smart cities: An integrative framework. In Proceedings of the 2012 45th Hawaii International Conference on System Science (HICSS), Maui, HI, USA, 4-7 January 2012; pp. 2289-2297.

46. Harrison, C.; Donnelly, I.A. A theory of smart cities. In Proceedings of the 55th Annual Meeting of the ISSS-2011, Hull, UK, 17-21 July 2011.

47. Nam, T.; Pardo, T.A. Conceptualizing smart city with dimensions of technology, people, and institutions. In Proceedings of the 12th Annual International Digital Government Research Conference: Digital Government Innovation in Challenging Times, College Park, MD, USA, 12-15 June 2011; pp. 282-291.

48. Angelidou, M. Smart city policies: A spatial approach. Cities 2014, 41, S3-S11. [CrossRef]

49. Paskaleva, K.A. Enabling the smart city: The progress of city e-governance in Europe. Int. J. Innov. Reg. Dev. 2009, 1, 405-422. [CrossRef]

50. Shelton, T.; Zook, M.; Wiig, A. The 'actually existing smart city'. Camb. J. Reg. Econ. Soc. 2015, 8, 13-25. [CrossRef]

51. Sassen, S. Talking Back to Your Intelligent City; McKinsey: Sydney, Australia, 2011.

52. Townsend, A.M. Smart Cities: Big Data, Civic Hackers, and the Quest for a New Utopia; WW Norton \& Company: New York, NY, USA, 2013.

53. Washburn, D.; Sindhu, U.; Balaouras, S.; Dines, R.A.; Hayes, N.; Nelson, L.E. Helping CIOs understand "smart city" initiatives. Growth 2009, 17, 1-17.

54. Piccialli, F.; Chianese, A. Editorial for FGCS Special Issue: The Internet of Cultural Things: Towards a Smart Cultural Heritage; Elsevier: Amsterdam, The Netherlands, 2018.

55. Rutten, P.; Culture \& Urban Regeneration. Cultural Activities \& Creative Industries, a Driving Force for Urban Regeneration; Finding \& Conclusions on the Economic Perspective; Urbact Culture Network: Helsinki, Finland, 2006.

56. Li, Y.; Hu, C.; Huang, C.; Duan, L. The concept of smart tourism in the context of tourism information services. Tour. Manag. 2017, 58, 293-300. [CrossRef] 
57. Gretzel, U.; Sigala, M.; Xiang, Z.; Koo, C. Smart tourism: Foundations and developments. Electron. Mark. 2015, 25, 179-188. [CrossRef]

58. Buhalis, D.; Amaranggana, A. Smart tourism destinations. In Information and Communication Technologies in Tourism 2014; Springer: Cham, Switzerland, 2013; pp. 553-564.

59. Boes, K.; Buhalis, D.; Inversini, A. Conceptualising smart tourism destination dimensions. In Information and Communication Technologies Tourism 2015; Springer: Cham, Switzerland, 2015; pp. 391-403.

60. Lamsfus, C.; Martín, D.; Alzua-Sorzabal, A.; Torres-Manzanera, E. Smart tourism destinations: An extended conception of smart cities focusing on human mobility. In Information and Communication Technologies Tourism 2015; Springer: Cham, Switzerland, 2015; pp. 363-375.

61. Wang, D.; Li, X.R.; Li, Y. China's "smart tourism destination" initiative: A taste of the service-dominant logic. J. Destin. Mark. Manag. 2013, 2, 59-61. [CrossRef]

62. Guo, Y.; Liu, H.; Chai, Y. The embedding convergence of smart cities and tourism internet of things in China: An advance perspective. Adv. Hosp. Tour. Res. AHTR 2014, 2, 54-69.

63. Ramkissoon, H.; Nunkoo, R. City image and perceived tourism impact: Evidence from Port Louis, Mauritius. Int. J. Hosp. Tour. Adm. 2011, 12, 123-143. [CrossRef]

64. Höjer, M.; Wangel, J. Smart sustainable cities: Definition and challenges. In ICT Innovations for Sustainability; Springer: Cham, Switzerland, 2015; pp. 333-349.

65. Harrison, C.; Eckman, B.; Hamilton, R.; Hartswick, P.; Kalagnanam, J.; Paraszczak, J.; Williams, P. Foundations for smarter cities. IBM J. Res. Dev. 2010, 54, 1-16. [CrossRef]

66. Khatoun, R.; Zeadally, S. Smart cities: Concepts, architectures, research opportunities. Commun. ACM 2016, 59, 46-57. [CrossRef]

(C) 2019 by the authors. Licensee MDPI, Basel, Switzerland. This article is an open access article distributed under the terms and conditions of the Creative Commons Attribution (CC BY) license (http://creativecommons.org/licenses/by/4.0/). 